\title{
Sustainable Tourism Management
}

By John Swarbrooke. CABI (10 E. 40th Street, Suite 3203, New York NY 10016, USA) 1999, $\mathrm{x}+371 \mathrm{pp}$ (index, tables, figures, bibliography) $\$ 45.00 \mathrm{Hbk}$. ISBN 0-851-99314-1.

\section{Ralf Buckley}

Griffith University, Australia

This is an interesting text, with an inappropriate title. With 34 lecture-length chapters, the book would be a solid university text on the social aspects of tourism; but it is only marginally about sustainable development or management. To start, only the social dimension of sustainability is considered. Swarbrooke argues that the natural environment is overemphasized (such as pp. 5, 11). This is patently incorrect. The most critical issue facing global society is the impact of human activity on the natural environment. Certainly, social issues are important, because they set apparently insurmountable barriers to sustainability. However, without the environmental dimension, this book is not about sustainability.

Nor is Sustainable Tourism Management about management. It mentions operations management, but only at corporate policy level. It mentions marketing and finance, but not how to manage them. Further, it says nothing about management structures. Actually, the book is also very Eurocentric. The destination resort of Benidorm is mentioned without explanation. So are gîtes, small-scale tourism accommodation on farms in France (p. 163). Driving offroad vehicles is considered "extreme". For residents of Latin America, Africa or Australia, this is a ridiculous attitude.

As these shortcomings suggest, the sparse treatment afforded the natural environment is the book's greatest weakness. Chapter 4 lists 29 "principles of sustainable tourism management” (pp. 41-43), but only one refers to the natural environment, and then only to belittle it. Table 5.1, a list of potential impacts on the natural environment, is drawn from another book with the date quoted incorrectly. This table, plus two pages of text, is the total coverage of the natural environment until p. 284, where there is a 
case study of the German tour operator, TUI. Its environmental policy is, in fact, well regarded, but Swarbrooke criticizes it by noting it says "little or nothing about the social and economic dimensions of sustainable tourism” (p. 287) and that TUI cares only about the environment because its customers do. But the reader is not told what is wrong with this orientation. The comment is a bit ironic, as well, because Swarbrooke also claims tourists are not concerned about sustainable development.

The text refers to several well-known 1997-98 books on tourism. There is little reference, however, to tourism research in environmental journals. By chapter 33, the reader can only conclude that the book contains little understanding of the environmental sciences. However, on p. 289, Swarbrooke raises an interesting question: whether four modern cars with catalytic converters, each carrying 3 passengers, are better or worse for the environment than a 20-year old coach with 12 people on board. This depends on the size of the coach, but these are the kind of questions that need answering to help tour operators to minimize impacts. Swarbrooke also mentions well-known industry environment management programs such as those of Canadian Pacific Hotels and Resorts, and the International Hotels Environment Initiative (p. 301). He notes that cost savings are the primary incentive for such programs. The author mentions the importance of environmental purchasing practices (p. 239) and emphasises that debates over carrying capacity, however defined, are sterile unless the concept can be implemented in practice (p. 225). Further, he recognizes that tourism impacts are generally far less than those of other industries. The UK's Peak District, as he rightly says, is "blighted by massive quarries” whose impacts far outweigh those of tourism footpaths (p. 164).

Considering its core theme, social impacts of tourism, the book has many interesting insights that make it well worth reading. Swarbrooke notes that industry selfregulation and tourist education "continue to achieve only modest success” (p. 89). He argues that "community consensus" is somewhat mythical; and, moreover, “community leaders" often are self-appointed (p. 125). He notes the indirect role of mass media in advertising tourism off the beaten track; and thus, he concludes that sustainable tourism may not be achievable. Even in the social arena, there are some myths that Swarbrooke perpetuates. He argues that in tourism, "the service delivered by employees is the core of the product which is offered” (p. 230). Service quality is 
certainly important, but for many tourists it is places, sights, and activities that are the core product. Indeed, most people encounter rude and unhelpful people during their travels, but this rarely stops them from going to places. In many respects, the text is sometimes moralistic, inconsistent, and trite. Some citations are missing, such as Filion and USTDC (p. 319). Others are spelled incorrectly, such as Lundberg instead of Lindberg (p. 364). These are, though, minor quibbles.

One oft-mentioned issue is demarketing-the use of marketing tools to change the number, type, or timing of tourists visiting a particular destination. Swarbrooke distinguishes demarketing by product, price, place, and promotion (p. 221), with particular reference to carrying capacity. Some of Swarbrooke's views may prove controversial. For instance, he says money spent teaching tourists about the environment would better be spent teaching them about HIV (p. 33). He claims that "sustainable tourism is about who has the power" (p. 41). He argues that tourists are entitled to hedonism, and that on holiday there is "no need to be sensible" (p. 144). He argues that tourism workers are commonly exploited (p. 232). He refers to direct negotiations between individual tourists and ultimate tourism suppliers as "fair trade" (an unusual use of the term), suggesting that tour and travel agents are in some way unfair. Finally, in an intriguing but undefined turn of phrase, he claims that ecotourism has become “too big for its boots” (p. 312).

Chapter 33, "Conclusions", lists potential criticisms of the book: too broad, superficial, or repetitive. To this reviewer, it is not so. As a lecture-style overview of tourism and human societies, it is a valuable contribution to the literature. As noted at the outset, however, it is only about one dimension of sustainability, and only marginally about management. One feature of a readable text is phrases that stick in the reader's mind. In this case, the best is surely Swarbrooke's classification of ideas (p. 24), into sacred cows, cash cows, and mad cows. As a linguistic construct, this is a logician's nightmare but it is a memorable turn of phase.

Ralf Buckley: International Center for Ecotourism Research, Griffith University, Queensland, Australia. Email R.buckley@mailbox.gu.edu.aul. 